\title{
LITERATURA NEGRA CARIBENHA, DESCOLONIZAÇÃO DO CÂNONE LITERÁRIO E CRÍTICA DECOLONIAL
}

\author{
BLACK CARIBBEAN LITERATURE, DECOLONIZATION OF THE \\ LITERARY CANON AND DECOLONIAL CRITICISM
}

\begin{abstract}
Cristian Souza de Sales ${ }^{1}$
\section{RESUMO}

O presente texto busca discutir como a escritora e intelectual negra caribenha Mayra Santos-Febres, a partir do romance afrodiaspórico $F e$ en Disfraz, promove intervenções epistemológicas que para descolonização do cânone literário. Desta forma, o texto evidencia como a pensadora contemporânea assenta novas formas de narrar que subvertem uma tradição e reatualizam/revitalizam o campo literário latino-americano e caribenho. Ao mesmo tempo, a luz da crítica decolonial, enfatizamos como Santos-Febres oferece-nos contribuições epistêmicas que preenchem os vazios da historicidade acerca das relações coloniais e contestam as "formas estreitas de pensar" (GROSFOGUEL, 2007). Ao fazer isso, a autora estabelece um ponto de vista crítico para instaurar uma ruptura radical com os padrões instituídos pela colonialidade de poder, do saber e do ser (QUIJANO, 2000; MALDONADO-TORRES, 2016), bem como operar a constituição de "una nueva literatura insurgente de la afrodescendencia". (ARROYO PIZARRO, 2013).
\end{abstract}

Palavras-chave: Escritoras negras caribenhas; Literatura afro-diaspórica; Decolonialidade; Insurgências negras epistêmicas.

\begin{abstract}
This text seeks to discuss how the black Caribbean writer and intellectual Mayra Santos-Febres, based on the Afro-diasporic novel Fe en Disfraz, promotes epistemological interventions that decolonize the literary canon. In this way, the text shows how the contemporary thinker settles new ways of narrating that subvert a tradition and refresh/ revitalize the Latin American and Caribbean literary field. At the same time, in light of decolonial criticism, we emphasize how Santos-Febres offers us epistemic contributions that fill the gaps in historicity about colonial relations and challenge "narrow ways of thinking" (GROSFOGUEL, 2007). In doing so, the author establishes a critical point of view to introduce a radical break with the standards instituted by the coloniality of power, knowledge, and being (QUIJANO, 2000; MALDONADO-TORRES, 2016), as well as operating the constitution of " a new insurgent literature of African descent." (ARROYO PIZARRO, 2013).
\end{abstract}

Keywords: Black Caribbean writers; Afro-diasporic literature; Decoloniality; Black epistemic insurgencies.

\footnotetext{
${ }^{1}$ Atualmente é Professora da Universidade do Estado da Bahia (UNEB). Doutora pelo Programa de PósGraduação em Literatura e Cultura-PPGLitCult, da Universidade Federal da Bahia (UFBA). Mestra pelo Programa de Pós-Graduação em Estudo de Linguagens-PPGEL/UNEB. E-mail: crissaliessouza@gmail.com
} 


\section{MAYRA SANTOS-FEBRES: LA PIEL QUE ESCRIBO}

[...] Ser negra es la razón primordial por la cual soy escritora. [...] Son 3 desde que tengo conciencia: el Caribe, las sensaciones de estar viva en el Caribe (raza, género), las historias de mis ancestros. (Mayra Santos Febres, 2015)².

Em escritos jornalísticos, entrevistas, ensaios, contos e romances, Mayra SantosFebres deixa marcas quanto ao seu posicionamento epistêmico, artístico e crítico. Poeta, romancista, ensaísta e professora de literatura, nascida em 26 de fevereiro de 1966, em Porto Rico (Carolina), filha de professores, inicia contato com os livros desde a infância e começa a escrever com apenas cinco anos de idade, tornando-se uma das mais proeminentes e aclamadas escritoras e intelectuais negras contemporâneas. Com livros traduzidos para várias línguas (o francês, inglês, alemão e italiano), pode-se dizer que atua sem submissão às normas definidas pelo cânone nacional, critérios e parâmetros idealizados do que deva ser o texto literário.

Ainda nesta senda, publicando poesias desde 1984, em revistas e jornais internacionais como Casa de las Américas de Cuba, Página doce de Argentina, Revue Noir da França e Latin American Revue of Arts and Literature de Nova Iorque, entre outros, os textos da autora porto-riquenha, sobretudo a sua ficção, de uma maneira geral, realizam uma retomada de acontecimentos históricos acerca da presença negro-africana nas Américas e Caribe. Em muitos aspectos, a sua voz desencadeia um campo de reflexão bastante variado, afetando os planos temático e formal de sua literatura, "haciendo contrapesso al tradicional rechazo e invisiblización para abogar a favor de un reconocimiento de lo negro". (SANTOS-FEBRES, 2010, p. 67).

Por conseguinte, as obras ficcionais arrebatam a crítica e teoria literária, tanto nacional como internacional conferindo a Santos-Febres um reconhecimento irrestrito por seu projeto estético, político e crítico. Logo, situadas em uma determinada ótica, os elementos

\footnotetext{
${ }^{2}$ Ver entrevista completa realizada por Lucía Asué Mbomío Rubio, Disponível em https://afrofeminas.com/2015/07/01/ser-negra-es-la-razon-primordial-por-la-cual-soy-escritora-entrevista-amayra-santos-febres/acesso em: 01 de dez.2020.
} 


\section{Revista \\ Debates Insubmissos}

organizados revelam a força poética de uma autoria negra feminina que cria uma gramática própria com as ações políticas ancoradas numa linguagem antirracista e antissexista. Uma gramática afro-diaspórica para "hablar de la raza, identidad de género y la negritud en Puerto Rico". (SANTOS-FEBRES, 2010, p. 68-69).

De maneira destacada, Mayra entrecruza as formas narrativas híbridas, esgarçando os limites entre o ficcional, o ensaístico e o documental, rasurando os estatutos da ficção e da historiografia, assim como as estratégias narrativas contemporâneas para referenciar e visibilizar "los saberes afrodescendientes, caribeños, de género y puertorriqueños... y diásporas". (SANTOS FEBRES, 2020, fonte eletrônica). Dentre estes pilares, a escritora assevera:

[...] 99\% de mi narrativa está basada en investigación. También 99\% de mis olvidos están basados en la invisibilización de los saberes afrodescendientes, caribeños, de género y puertorriqueños. [...] Soy una escritora afrodescendiente puertorriqueña. He publicado veintiocho libros que consistentemente trabajan los temas que me apasionan: raza, pluralidades en identidad de género, Caribe, diásporas, modernidad. En poesía, cuento, ensayo, performance, novela, teatro, guion de cine. $Y$ me falta todavía. Veremos a ver con qué salgo en el futuro. (SANTOS FEBRES, 2020, fonte eletrônica).

A despeito disso, os escritos da autora caribenha se espalham em diversos trabalhos acadêmicos, enfileiram-se nas estantes de bibliotecas nacionais e estrangeiras, entre romances, contos, poesias, ensaios, artigos, crônicas, histórias infantis etc. Com uma dinâmica interna marcada pela insurgência, apresenta um exercício criativo, crítico e teórico que não se restringe apenas ao campo literário ou ensaístico. Por meio de entrevistas, palestras, intervenções públicas, Santos-Febres faz emergir narrativas que evocam um Caribe Negro: soterrado, emudecido e apagado por uma historiografia, teoria e crítica literárias. Em face disso, busca "transformar os sistemas de dominação e de exploração da actual matriz de poder colonial do sistema-mundo patriarcal/capitalista colonial/moderno". (GROSFOGUEL, 2008, p. 140)

Com um amplo repertório, Mayra Santos-Febres publicou até o momento as seguintes obras: Anamú y manigua (1991/poesia); Pez de vidrio (1994/contos); Oso Blanco (1996/contos); El cuerpo correcto (1996/contos); El orden escapado (1991/poesia); Tercer 


\section{rovitata 6 \\ Debates Insubmissos}

mundo (2000/poesia); Sirena Selena vestida de pena (2000/novela), já traduzido para o inglês, francês e italiano e finalista do Prêmio Rómulo Gallegos na categoria romance em 2001; Cualquier miércoles soy tuya (2002/romance); Sobre piel y papel (2005/ensaios); Boat People (2005/poesia); Nuestra Señora de la Noche (2006/novela); Ernesto , El domador de los suenos (2008/literatura infanto-juvenil); Fe en Disfraz (2009/romance); Tratado de medicina natural para hombres melancólicos (2011/ensaios); En el Ojo del Huracan: Nueva Antologia de Narradores Puertorriquenos (2011); El baile de la vida (2012); La amante de Gardel (2015/romance); Huracanada (2018/poesia); Antes que llegue la luz (2021/romance), entre outras.

Seguindo essa cartografia, a escritora também se destaca por suas estratégias de atuação política, acadêmica e intelectual. Como podemos ver, coloca em movimento uma práxis negra para além de simples um engajamento funcional nos quadros universitários. Desde um ponto de vista crítico e teórico para um verdadeiro projeto de descolonização, Santos-Febres articula, movimenta e agencia o que bell hooks (1995) chama de "política do cotidiano", tendo em vista que a inserção pública e epistêmica não está divorciada da comunidade afro-porto-riquenha ${ }^{3}$.

Em grande parte, a autora alimenta-se da palavra aguerrida, da radicalidade analítica, de uma sintaxe afro-atlântica - portanto, da persistência e "insurgência negra políticoepistêmica" (SALES, 2020), demonstrando vigor dentro de seus domínios de pensamento e práxis intelectual. Podemos discorrer, inclusive, que cada palavra carrega em si um significado cultural e, historicamente, refeito dentro de uma tradição literária e epistêmica. Essa tradição que ainda insiste em representar mulheres afro-latino-americanas e caribenhas para destituir a existência humana. Isso implica repercussões políticas enormes para superar as armadilhas do colonialismo.

\footnotetext{
${ }^{3}$ Fora do espaço da universidade, existe tempo e lugar para outras intervenções, tendo em vista que a escritora porto-riquenha mantém ativa as suas redes sociais opinando sobre temas variados: racismo, gênero, sexismo, negritude, literatura, afro-futurismo etc. Além disso, faz palestras em escolas públicas, organiza um festival literário e coordena o coletivo RedLiterária.
} 
Considerando esses pontos, nas palavras de Catharine Walsh (2008, p. 131), movida por "esfuerzos históricos, insurgentes y trascendentales", Santos-Febres exercita "articulaciones y construcciones distintas que alienten un cambio radical e descolonizador do pensamiento" para balançar as estruturas. (WALSH, 2008, p. 134). Sob uma perspectiva feminina negra e anticapitalista, de modo a garantir reparação e justiça, a autora demonstra os obstáculos de que necessita transpor para "nombrar el negro o a la negra, al mulato... de la discusión sobre prejuicio racial? [...] La gente se pone inquieta". (SANTOS-FEBRES, 2010, p. 67).

Nesse processo de descolonização, desempenha uma função importante enquanto intelectual negra, uma vez que a sua produção de conhecimento desmantela "as formas de racismo epistêmico que fazem parte das humanidades e das ciências". Acrescido a isso, desarquiva narrativas de "las ancestras" (ARROYO PIZARRO, 2013) apontando outras possibilidades epistemológicas que consideram diferentes tipos de saberes, novas alternativas de vida e pensamento ${ }^{4}$. Sendo assim, a radicalidade desse empreendimento se expressa através de transformações na escrita para reescrita e, consequentemente, reinterpretação da historiografia, teoria e crítica literárias latino-americanas e caribenhas. (MALDONADOTORRES, 2016, p. 75).

A esse respeito, propondo uma radical mudança na concepção da obra de arte, inserindo-se no contexto de um processo de conhecimento e reinterpretação da realidade nacional, a pensadora negra não só desafia "as formas estreitas de pensar as relações coloniais" e, ao mesmo tempo, questiona a "visão hegemônica branca acerca das minorias discriminadas" em Porto Rico. Assim concebida, essas formas hegemônicas de pensamento ganharam intensa projeção nos textos literários e historiográficos. (GROSFOGUEL, 2007, p. 178).

\footnotetext{
${ }^{4}$ Por todo o texto, a palavra "as ancestrais" está grafada em itálico las ancestras para acompanhar/repetir um gesto epistêmico de Yolanda Arroyo Pizarro no ensaio Por que hablar de las ancestras. Além disso, incorporo essa gramática afro-diaspórica como parte de minha proposta teórica e crítica para assentar outros saberes circunscritos nos textos de intelectuais negras diaspóricas, assim como para provocar os vazios e silêncios da historiografia colonial nas Américas e Caribe.
} 


\section{Revista \\ Debates Insubmissos}

Recordemos que racismo no es sino la transposición de los sistemas valorativos de la esclavitud a la sociedade post-esclavista, una manera de mantener a las poblaciones negras al margen de la sociedade sin la evidencia legal y econômica de dicha marginación. (SANTOS-FEBRES, 2010, p. 69).

Nesses temos, Santos-Febres é uma intelectual negra diaspórica que assume a tarefa de “estimular, proporcionar e permitir percepções alternativas e práticas que desloquem discursos e poderes prevalecentes" em Porto Rico. (WEST, 1999, p. 13). Em outras palavras, assenta uma práxis negra intelectual para dar voz a saberes que sempre existiram, contudo, permaneceram historicamente silenciados por "epistemologias eurocentradas". (SANTOS; MENESES, 2010). De certa forma, essa práxis negra resiste, questiona e busca "mudar padrões coloniais do ser, do saber e do poder" infligidos por discursos literários na América Latina e Caribe. (MALDONADO-TORRES, 2016, p. 88).

Diante deste quadro, na tarefa de produzir conhecimento, expressa um ponto de vista caracterizado "por uma prática insurgente e engajada" perturbadora do status quo, a qual está muito bem articulada aos planos da teoria e prática, questionando e criticando explicitamente os legados coloniais. (WEST, 1999, p. 13, grifos do autor). Por meio dessas concepções, discursivamente coerente e, por isso mesmo, fascinante, através da intersecção entre gênero, raça, classe e sexualidade, Santos-Febres captura as frequências político-sociais e as tensões histórico-culturais nos mais diferentes contextos. Nesse sentido, podemos demonstrar essa assertiva com um fragmento de uma entrevista:

[...] investigo [...] sobre diversos temas de raza, racialización, caribeñidad, nuevas formas de la escritura creativa. [...] La colonización es el ejercicio continuo de olvidar. Hay que olvidar quién eres para que quieras convertirte en el "otro". El "otro" blanco, varón, europeo o estadounidense, el otro rico, primermundista, el otro que no eres tú. (SANTOS FEBRES, 2020, fonte eletrônica).

Quanto às suas personagens, Santos-Febres constrói tramas literárias em que as protagonistas desempenham papeis sociais expressivos que estimulam discussões sobre descolonização. Apontando possibilidades de transformações de discursos, fugindo dos clichês e estereótipos presentes em obras de autores canônicos porto-riquenhos, elas aparecem como escritoras, intelectuais, artistas, professoras, curandeiras, cozinheiras etc. Em sua maneira de 


\section{Revista}

ser, agir, pensar e existir, despertam encanto e inspiração como a enfermeira Micaela Thorné (enfermeira) e sua avó Mano Santa (curandeira) em La amante de Cardel (2015)5.

Nesse viés, movendo-se entre fronteiras geográficas, culturais e linguísticas, as personagens de contos, romances e novelas percorrem os mais diversos lugares sociais, construindo percepções diferentes sobre vidas negras em diáspora. Em Nuestra Senhora de la noche (2008), além de se debruçar com profundidade e delicadeza nas questões vividas por mulheres afrodescendentes, desenvolve uma nova relação com a linguagem que as retira do lugar de sujeito passivo.

Não obstante, semeadas por uma "insurgência negra epistêmica" (SALES, 2020), as narrativas também destacam trajetórias de personagens em espaços públicos, nos quais trabalham, militam, escrevem, intervém e atuam na gestão de suas emoções e afetos (dor, tristeza, esperança, medo, alegria etc.). Assim sendo, em Sirena Serena vestida de pena (2000), Santos-Febres propõe relações sociais concretas de sujeitos/as negros/as que são protagonistas de suas próprias histórias. Por conseguinte, à procura de restituir uma humanidade e valorizar a diversidade para refazer um imaginário colonial, elas confrontam posturas ideológicas sustentadas por práticas racistas, machistas, classistas, capitalistas e LGBTfóbicas.

Nas obras de Santos-Febres, outro ponto de insurgência negra epistêmica que interessa para o nosso estudo diz respeito à ancestralidade negro-africana e os legados de luta e resistência de "las ancestras". Dentre as muitas questões incorporadas, a ancestralidade assenta o lócus da enunciação para ligar e religar temporalidades: passado, presente e constituir um futuro. Para além da construção de conceitos, importa a escritora uma conexão das personagens com a matriz negro-africana através de cosmovisões, cosmologias, saberes ancestrais, religiosidades, espiritualidades, o que afeta todas as dimensões da existência social.

\footnotetext{
${ }^{5}$ Micaela Thorné, personagem-protagonista, é descendente de uma linhagem ancestral de curandeiras de Porto Rico.
} 
Seguindo por esse argumento, nos romances Fe en Disfraz (2009) e La amante de Cardel (2015), em Marina y su olor (1996/conto) e La Hebra Rota (1996/conto); a ancestralidade combina, portanto, uma maneira de ser, estar, agir e existir com diversos saberes, diversas vozes, corpos, memórias e identidades etc. Nessas circunstâncias, o que surge, a partir daí, são novas formas de se constituir e organizar a sociedade, adotando esquemas políticos, sociais e culturais, os quais transcendem a relação de dominação e subordinação.

Em face do exposto, a ancestralidade negro-africana também organiza caminhos e reconecta as existências individuais e coletivas das personagens, assim como enfatiza o respeito a uma tradição e a preservação de conhecimentos herdados. Em outras palavras, passando por um conjunto muito variado de propostas intelectuais, a autora caribenha consegue "transcender epistemologicamente - ou seja, descolonizar - a epistemologia e o cânone ocidentais". (GROSFOGUEL, 2008, p.116).

Com base nisso, a ancestralidade negro-africana evidencia um conjunto da produção de conhecimento da linha de intensa experimentação criativa e radicalidade da práxis negra intelectual. Sendo assim, "no pensamento e no fazer descolonial verdadeiro" (MIGNOLO, 2008, p. 298), Mayra busca se emancipar das dominações epistemológicas - dos legados coloniais eurocêntricos; das estruturas de poder, controle e hegemonia praticados por uma historiografia, teoria e crítica literária latino-americana e caribenha. Dessa forma, a escrita negra feminina traz as vozes de sujeitos subalternizados para gerar ferramentas teóricas e conceituais próprias.

Sob esses dois prismas, podemos observar que a autora revigora os campos de produção artística e epistêmica com a grande abertura que traz, propicia - e pede - o debate em torno da história de "las ancestras". Não obstante, Santos-Febres fornece os elementos constitutivos a partir da epistemologia dos assentamentos de resistência ${ }^{6}$. Os "assentamentos

\footnotetext{
${ }^{6}$ Em minha tese de doutorado intitulada Assentamentos de resistência: intelectuais negras do Brasil e Caribe em insurgências epistêmicas (2020), buscamos tornar operatório o conceito de assentamento para ler, interpretar e traduzir a produção epistêmica e de conhecimento de mulheres negras em diáspora. Os assentamentos de
} 


\section{Revista \\ Debates Insubmissos}

de resistência" (SALES, 2020) são um tipo de pensamento, prática e perspectiva decolonial, que atua fortemente nos textos de autoria negra feminina latino-americana e caribenha para questionar, rasurar e se insurgir "a colonialidade do saber, do poder e do ser". (QUIJANO, 2005; MALDONADO-TORRES, 2007).

Nesse sentido, as obras de escritoras e intelectuais negras diaspóricas estão impregnadas por valores civilizatórios negro-africanos ligados aos orixás, aos ancestrais, iwas, vodus, nkisis, caboclos e outros encantados ${ }^{7}$ : Candomblés, Santería, Umbanda, Vudú, Rastafarianismo, Capoeira, etc. Desta feita, entre o visível e o invisível, essas vozes expressam toda riqueza cosmológica, epistemológica, cultural, filosófica, literária, linguística para assentar uma visão de mundo que se contrapõe ao pensamento ocidental através dos assentamentos de resistências.

Em seu máximo refinamento, o romance afrodiaspórico $\mathrm{Fe}$ en Disfraz desmantela o lugar da memória da escravidão, ao fazer emergir os legados da presença negro-africana em lugares como Colômbia, Cartagena de Índias (1743); Costa Rica - Valle de Matina (1719); Venezuela - Mérida (1645); Maracaibo (1985), Porto Rico e Brasil-Minas Gerais. Dentro das especificidades, da/na perspectiva de "las ancestras", os vestígios da escravização negroafricana reaparecem e, dessa vez, de difícil aterramento em um Caribe Negro, revelam-se a seletividade de uma reminiscência e o seu enquadramento por "formas eurocêntricas de conhecimento". (GROSFOGUEL, 2008, p. 128). Como consequência, tudo isso implica que outras concepções de mundo e narrativas sejam recuperadas e potencializadas.

resistência estão fortemente ligados à ancestralidade negro-africana e as histórias e os legados de resistência de las ancestras. Dessa forma, manifestam-se nas poesias, romances, contos e ensaios críticos de autoria negra. Assim, podemos observar esses assentamentos de resistência presentes no romance afrodiaspórico $\mathrm{Fe}$ en Disfraz (2009).

${ }^{7}$ Ver reflexão de HARDING, Rachel Elizabeth. Você tem direito à árvore da vida: spirituals afro-americanas e religiões da diáspora. Tradução de Christine J. Eida e Mariana Gadelha. In: REIS, Isabel Cristina F. dos; ROCHA, Solange P. Diáspora africana nas Américas. Cruz das Almas: EDUFRB; Belo Horizonte: Fino Traço, 2016. (Coleção Uniafro, 5). 


\section{LITERATURA INSURGENTE DE LA AFRODESCENDENCIA}

[...] En la literatura puertorriqueña, desde los inicios de estabelecimento de su canon, lo negro siempre ha representado lo irracional. Es el cuerpo, es lo animal, el origen antes de la palavra. A veces, com suerte, los personajes negros y negras que aparecen en las obras de la mayoría de nuestros escritores, cumpren un papel de víctimas, de depositários de una posición ideológica, pero nada más. (SANTOSFEBRES, 2010, p.: 144, grifos meus).

No ensaio Raza en la cultura puertorriqueña, Mayra Santos-Febres (2010) reflete que a literatura porto-riquenha canônica produziu e disseminou representações ficcionais depreciativas da população negra (homens e mulheres) procedentes da "a colonialidade do saber, do poder e do ser". (QUIJANO, 2005; MALDONADO-TORRES, 2007), as quais foram perpetuadas nos imaginários social e coletivo latino-americano e caribenho. Ainda sob essa ótica, elabora um exame à base do pensamento ocidental europeu que se enraizou na produção epistêmica em Porto Rico.

Em seguida, investe na radicalização do argumento ao rever uma tradição literária, crítica e teórica, oferecendo releituras de obras, imagens e discursos de autores/autoras. Sendo assim, Santos-Febres elabora uma perspectiva crítica capaz de transcender e desmitificar preconceitos e produção de sentidos, os quais seguem os pressupostos ocidentais do mundo moderno/colonial. Ao construir caminhos para encenar uma pluralidade de vozes, a sua postura epistêmica funciona para desnaturalizar processos de dominação relacionados a uma pressuposta de relação superioridade/inferioridade entre dominantes e dominados. (QUIJANO, 2005).

Ao analisar algumas obras literárias consideradas canônicas, Santos-Febres enfatiza que solapam representações estereotipadas e depreciativas que vão desde a mulata trágica ("un mito y un hito de la literatura racial") até mãe preta/ama de leite. Associada a essa visão, a imagem da mulata trágica aparece como uma filha bastarda, fruto de uma relação incestuosa, "desvalorizada moral y sexualmente", considerada uma figura perigosa aos valores disseminados pela família branca e escravocrata. (RIVERA-CASELLAS, 2011, p. 100). 
De certo modo, no Caribe Hispânico ${ }^{8}$, essas imagens da mulata trágica estão presentes na novela Cecilia Valdés $(1839,1882)$ do cubano Cirilo Villaverde; no drama La Cuarterona (1867) do porto-riquenho Alejandro Tapia y Rivera; Leyendas puertorriqueñas (“La hija de la mulata", 1799) e La negra azul do escritor porto-riquenho de Cayetano Coll e Toste (18501930) ${ }^{9}$; entre outras. No contexto latino-americano, encontramos esses discursos coloniais racistas e sexistas nas seguintes obras brasileiras: As vítimas-algozes: quadros da escravidão de Joaquim Manoel de Macedo (1869); A Escrava Isaura de Bernardo Guimarães (1875); $O$ Cortiço de Aluísio Azevedo (1890), entre outras. Salvo raras exceções, esses e outros autores/autoras pertencentes ao cânone nacional, tornaram-se influências e referências estéticas nas literaturas produzidas dos séculos XIX e $\mathrm{XX}^{10}$. Curiosamente, no conjunto de sua atuação, definindo parâmetros e modos de saber/fazer/conhecer, conduziram a formação de um campo da narrativa como instrumento de poder colonial em que as representações circularam (e ainda circulam) nos imaginários nas Américas e Caribe.

Em termos gerais, Santos-Febres ainda menciona os escritos do poeta porto-riquenho Luis Palés Matos (1898-1959) em Tun-Tún se passa Grifería (1937), e, relembra que se, por um lado, uma parte de suas obras "denuncia el racismo boricua, por outro se exalta la suposta sensualidade, sonoridade, sexualidade negra como fuerza vital de la identidad puertorriqueña”. (SANTOS-FEBRES, 2011, p. 145). Por essa razão, ao analisar como essa colonialidade do saber/do poder se inscreve nos textos literários de autoras não negras, cita o conto Cuando las mujeres quieren a los hombres, da escritora porto-riquenha Rosario Ferré

\footnotetext{
${ }^{8} \mathrm{O}$ Caribe Hispânico é constituído de povos de três regiões: Porto Rico, Cuba e República Dominicana.

${ }^{9}$ Ver cartografia crítica e literária construída por Marie Ramos Rosado em La mujer negra en la cultura puertorriqueña (1999).

${ }^{10}$ Sem dúvida, não se pode apagar, todavia, que a escritora afro-brasileira Maria Firmina dos Reis com o romance Úrsula (1859), assim como os poemas de escritora porto-riquenha Julia Constanza Burgos García (1914-1953) destoavam (destoam) dos discursos literários que circulam nos textos dos autores mencionados. Mas, infelizmente, por causa do "racismo epistêmico" (GROSFOGUEL, 2007/2016) e de outras condições políticas, históricas e culturais impostas, ambas as escritoras foram submetidas aos processos de silenciamento e invisiblização na Historiografia, Teoria e Crítica literárias.
} 


\section{Revista \\ Debates Insubmissos}

Ramírez (1938-2016); e o romance La ultima noche que pasé contigo (1991) da escritora cubana Mayra Montero, entre outros ${ }^{11}$.

Partindo desse contexto, Mayra problematiza a incidência de um modelo articulado de pensamento colonial disseminado pelo cânone literário latino-americano e caribenho, as maneiras de definir as formas literárias que resultaram em um processo de inferiorização /desumanização de mulheres africanas e negras. Como consequência disso, partindo do "espelho eurocêntrico" onde a imagem do/a colonizado/a surge sempre distorcida (QUIJANO, 2005), a pensadora confronta as diferentes dimensões da colonialidade associadas ao racismo/sexismo:

El cuento de Rosarito aparecen dos Isabeles, la esposa (obviamente blanca) y chilla (negra, Isabel Luberza) [...] la afamada duenã del prostíbulo más poderoso de Ponce. [...] El mundo de la mujer blanca es descrito com precisión y nos resulta plenamente reconocible. Pero el de la mujer negra brilla por su ausencia. Está representada tan sólo por su cuerpo, la sexualidade, lo erótico. No tiene ni cultura ni costumbres, ni sentido mayor que el de cuerpo. (SANTOS-FEBRES, 2011, p. 146).

Considerando esses importantes eixos, no ensaio Hablar de las ancestras, Yolanda Arroyo Pizarro (2013, p. 27) tece uma análise não só acerca dos vazios da historiografia colonial, bem como trava uma batalha constante com o eurocentrismo no que diz respeito " $a$ las historias contadas sobre esclavos y esclavas". Ao introduzir essa discussão, dispondo de outras ferramentas, a escritora e intelectual negra porto-riquenha coloca em xeque um sistema de valores disseminados por hegemonias de pensamentos para reconstruir condições de poder, de ser e de saber.

Para Arroyo Pizarro, em Hablar de las ancestras, é necessário reordenar a geopolítica do conhecimento (MALDONADO-TORRES, 2008) nos campos literário latino-americano e caribenho para desfazer as imagens subalternizadas de mulheres africanas e negras reproduzidas pela colonialidade do poder - em particular, o poder colonial (MIGNOLO, 2003, p. 39) -, do saber e do ser (MALDONADO-TORRES, 2008, p. 147). Nesse processo,

\footnotetext{
${ }^{11} \mathrm{O}$ presente conto está publicado no primeiro livro da autora porto-riquenha intitulado Papeles de Pandora (1976).
} 
deve-se ressaltar que essas "mujeres resistieron de manera activa y respondieron frontalmente contra el sistema esclavista y todas sus formas de opresión". É importante salientar "sus estrategias de resistencia fueron variadas e múltiplas". (ARROYO PIZARRO, 2013, pp. 35-36).

De acordo Santos e Meneses (2010, p.11), o colonialismo além de todas as dominações por que é identificado, foi também uma dominação epistemológica, estabelecendo "uma relação extremamente desigual entre saberes que conduziu a supressão de muitas formas de saber próprias dos povos e nações colonizados, relegando-os à subalternidade”. Por isso, no contexto do ensaio Hablar de las ancestras, ao chamamento a uma literatura afro-portoriquenha e/ou literatura negra caribenha e "epistemologia negra caribenha" (SALES, 2020), constituem-se como território para os assentamentos de resistência.

A partir dos assentamentos de resistência, opera-se a reconstrução de narrativas e memórias afro-atlânticas. De forma complementar, trata-se de uma prática decolonial que reposiciona corpos negros femininos insurgentes como produtores de saberes com seus modos específicos de ser, se relacionar e interpretar o mundo. Por sua vez, os assentamentos de resistência recuperam um pensamento alternativo e a capacidade criativa dos povos colonizados

De forma similar, como exemplo da mudança de abordagem epistêmica, crítica e ética que rompe com o silenciamento, a qual tem sido proposta por Mayra Santos-Febres, citamos outras escritoras e intelectuais negras caribenhas contemporâneas: Marie Ramos Rosado, Gloriann Sacha Antonetty Lebrón, Zaira Rivera Casellas, Yvonne Denis Rosario, Maritza Quiñones-Rivera, entre outras. De fato, essa geração de "mulheres negras, tão invisíveis justamente por serem negras e mulheres", a partir "do artesanato da palavra, da dor, da literatura e da poesia" têm narrado suas experiências e vivências de suas perspectivas. (ARROYO PIZARRO, 2017, fonte eletrônica).

A partir desses elementos, Arroyo Pizarro afirma que se torna indispensável pensar na construção de "novos modelos epistemológicos", críticos e literários capazes de atender às 


\section{Revista \\ Debates Insubmissos}

especificidades, os quais envolvem narrar às histórias e os legados de luta e resistência de las ancestras nas Américas e Caribe. (WALSH, 2005). Nesse deslocamento, observando distintas estratégias discursivas e seus indicativos, extraímos a principal força orientadora de suas reflexões:

[...] desde una nueva Literatura insurgente de la Afrodescendencia. Y digo nueva porque em Puerto Rico tenemos muy poco o casi nada de literatura que describa a nuestras antepasadas. No tenemos el género o la categoria slave narratives como llaman em otros lugares. (ARROYO PIZARRO, 2013, p. 27, grifos da autora).

De outro lado, intensificando saberes encruzilhados no diálogo com Santos-Febres, Arroyo Pizarro sugere questionar e desconstruir o que foi construído pela colonialidade do saber, do poder e do ser, especialmente nos textos em que as mulheres africanas e negras aparecem como sujeitos passivos e somente como vítimas da dominação colonial. (MIGNOLO, 2003; MALDONADO-TORRES, 2008). Contudo, isso vai além muito da descolonização do pensamento, porque a pensadora supõe também a construção e a concepção de "una nueva Literatura insurgente de la Afrodescendencia". (ARROYO PIZARRO, 2013, p. 27).

Desta maneira, Yolanda Arroyo Pizarro assevera que a reconstrução e desconstrução radical do ser, do poder e do saber, por escritoras e intelectuais negras caribenhas, implica em um fazer literário para que as antepassadas sejam narradas "desde el único lugar ideológico y correcto: desde la Resistencia". (ARROYO PIZARRO, 2013, p. 33). Nesse des-a-fio epistêmico-político, trata-se de um posicionamento para dar a voz aos corpos negros marcados por múltiplas violências. Apesar de trazer à tona memórias traumáticas, revelam-se processos históricos intencionalmente apagados.

De acordo com a autora supracitada, essa "Literatura insurgente de la Afrodescendencia" rompe com essa secular tradição de silenciamento de las ancestras, tornando audíveis e visíveis vozes, trajetórias. Ademais, esse enfoque quer se estabelecer como um projeto alternativo ao epistemicídio (SANTOS, 1995, CARNEIRO, 2005) e o racismo epistêmico (GROSFOGUEL, 2007/2016). Segundo Carneiro (2005, p. 94), o epistemicídio "é, para além da anulação e desqualificação do conhecimento dos povos 


\section{Revista
Debates Insubmissos}

subjugados", pois se manifesta como "um processo persistente de produção da indigência cultural: pela negação ao acesso à educação, sobretudo de qualidade; pela produção da inferiorização intelectual", incluindo o "rebaixamento da capacidade cognitiva".

Dessa maneira, Zaira Rivera-Casellas (2001, p. 99) analisa que a literatura negra portoriquenha contemporânea tem contribuído para modificar a crítica, a teoria e "la historia de la literatura puertorriqueña", uma que vez busca tornar audíveis e visíveis narrativas produzidas "por cimarrones o esclavos durante el siglo XIX”. Assim exposto, não há dúvida de que obras literárias como Fe en Disfraz de Mayra Santos Febres (2009) e a antologia de conto las Negras de Yolanda Arroyo Pizarro (2012), colaboram para desvelar por completo "interpretaciones de la literatura y la identidad nacional caribenha".

A partir dessa diversidade epistêmica, textos de autoria negra feminina constituem um novo corpus literário "en el que las voces de los esclavos y las esclavas" reconstroem o passado nas Américas e Caribe. Assumindo posição antagônica ao cânone ocidental, as obras literárias de Mayra Santos Febres e Yolanda Arroyo Pizarro se abastecem dos relatos de "mujeres y hombres africanos y sus descendientes", com vivências e experiências centradas "en las esclavitud". Ambas as escritoras caribenhas rasuram uma tradição literária entrecruzando "análisis histórico y literario para deconstruir los significados de la esclavitud y la emancipación" (RIVERA-CASELLAS, 2011, p. 99).

Concordando com Mayra Santos-Febres e Yolanda Arroyo Pizarro, Rivera-Casellas garante que existe uma posição conservadora adotada pela história, crítica e literatura latinoamericana e caribenha - que naturaliza e alicerça as ideais eurocêntricas, sexistas e racistas no interior de uma tradição forjada pela colonialidade do saber/do poder. Mais especificamente, essas ideias circulam como heranças coloniais nos textos de autores/autoras representantes do cânone nacional, os quais classificam e inferiorizam diferenças culturais com propósito de manter a dominação, hierarquização, subjugação e exploração de seus corpos/mentes. 
A partir dessas premissas, é, nesse sentido, que Rivera-Casellas também propõe repensar as referências canônicas e eurocêntricas, visando novas composições epistêmicas para descolonizar o conhecimento:

Sin embargo, en la literatura puertorriqueña contemporánea percibo textos que nos permiten acceder, desde la ficción, a ese silencio para repensar la arbitrariedad de imágenes y valores que comparten las representaciones culturales de los miembros de la diáspora africana en las Américas y el Caribe. (RIVERA-CASELLAS, 2011, p. 99).

Sob esse prisma, em $\mathrm{Fe}$ en Disfraz, Santos-Febres colabora para re-fundar e assentar um movimento de resistência epistemológica, literária, teórica e política. Na encruzilhada entre historiografia e literatura, "lo que sí es necessário desmontar el cuento que define lo negro como negativo en su especificidad histórica". (SANTOS-FEBRES, 2011, p. 136). Com a força da radicalidade, à espera de revisões, esse gesto decolonial mobiliza um projeto de decolonização do cânone literário e historiográfico, sendo capaz de abranger os mais diversos caminhos críticos.

\section{LA POÉTICA DE LA ESCLAVITUD: RUPTURA E AFIRMAÇÃO}

Homenaje a la resistencia, a la rebeldia, a la entrega amorosa, al recuerdo de la tierra para siempre perdida en medio de la nada inconmensurable, tanto como la inmensidad de la travessia oceânica no perdida, sí impuesta, sí obligada, aceptar como viaje de placer agónico, sin boleto de vuelta. (ARROYO PIZARRO, 2013, p. 108).

No âmbito da literatura porto-riquenha, há que se ressaltar um tipo de narrativa ficcional marcada por um discurso que possui suas singularidades e, assim, pode se distinguir de outras produções contemporâneas. Por isso mesmo, considerando-se a importância do lugar da enunciação, com a multiplicidade de vozes, textos e assuntos, escritoras negras caribenhas impuseram o reconhecimento das múltiplas expressões culturais dos grupos considerados subalternos.

Como resultado disso, dentre os inúmeros projetos em pauta, essas vozes femininas reconfiguram acontecimentos históricos com um objetivo particular: "presentar una versión 


\section{Revista \\ Debates Insubmissos}

propia de la historia y elaborar nuevas imágenes" associadas as mulheres africanas e negras em diáspora. Segundo Zaira, descortinando um projeto de dominação, "la escritura antiesclavista" elou "la poética de la esclavitud" permite desconstruir as representações "de las mujeres negras en Puerto Rico". (RIVERA-CASELLAS, 2011, p. 100).

Diante dessa situação, verifica-se, em suas rearticulações discursivas, a presença de narrativas literárias que se afastam dos padrões da literatura canônica. Em outras palavras, este tipo de produção literária contemporânea se insere no interior de um movimento epistêmico e cultural mais amplo, em que a reescrita da história negra feminina é um ponto de partida da prosa de ficção porto-riquenha. Partindo dessa tendência, é importante, então, observar de que forma a literatura negra caribenha faz esse movimento no romance afrodiaspórico Fe en Disfraz.

Nessa mesma linha, "la escritura antiesclavista" e "la poética de la esclavitud, propostas respectivamente por Yolanda Pizarro (2011/2013) e Rivera Casellas (2011), em múltiplas posições e pontos de vista, focalizam cenários, personagens, enredos e, sobretudo, modos de narrar, que parecem evocar configurações particulares de resistência epistêmica. Ainda sem capítulo definitivo na história literária, movendo-se nas fronteiras e nas margens, essa atitude de insurgência organiza novos enfoques e incorpora transformações aos modelos narrativos operados pela ficção.

Em outra perspectiva, Ana Belén Martín Sevillano (2012: 6) explica que Ramón Luis Acevedo, em 1991, ao publicar uma antologia com narrativas de autoria feminina em Porto Rico, cujo título bastante eloquente: Del silencio al estallido: narrativa femenina puertorriqueña ${ }^{12}$, contribuiu para dar visibilidade a escrita feminina e reestruturar historiografia, teoria e crítica literárias. Nessa obra, sem problematizar a categoria raça, além

\footnotetext{
${ }^{12} \mathrm{Com}$ as novas escritas e escritoras, a obra promove a perturbação do cânone literário como um corpus que desafia silêncios e exclusões. Antes desta coletânea, não havia uma antologia desde 1986 que tratasse da presença feminina na literatura porto-riquenha. Nas décadas de oitenta e noventa, surgiram duas antologias, mas, principalmente, de escritores já consagrados, como é o caso de Ramón Luís Acevedo, Do silêncio ao surto: narrativa feminina porto-riquenha (Río Piedras: Editorial Cultural, 1991) e María M. Solá Aqui as mulheres contam.
} 


\section{Revista
Debates Insubmissos}

dos textos literários cartografados, o autor incluiu um ensaio em que afirmava "la riqueza de la narrativa puertorriqueña escrita por mujeres a partir de los años setenta". MARTÍNSEVILLANO, 2012, p. 6).

Apesar de um pequeno número inicial, esse conjunto de autoras e obras passou a fazer parte de uma "tradición literaria nacional", tornando-se vozes insubmissas que se articulam e confrontam os discursos dominantes. Buscando tecer fios contra opressões impostas pelo patriarcado, não apenas pela denúncia, mas, sobretudo, por um trabalho estético marcado pelo resgate de um passado histórico, demonstram que "[...] la mujer había ocupado siempre un lugar subalterno, como creadora y como sujeto de representación". (MARTíNSEVILLANO, 2012, p. 6).

A partir dos anos setenta, um importante número de mulheres preencheu os espaços dentro “del campo literario puertorriqueñ”o com obras de qualidade, modificando estilos, gêneros e temáticas abordadas em um território dominando por vozes masculinas historicamente. Com riqueza estética, em menos de duas décadas, essas escritoras "modifican radicalmente el panorama literário" da ilha caribenha. Nesse cenário transformado pela ótica feminina, autoras como Rosario Ferré, Magali García Ramis, Carmen Lugo Filippi, Mayra Montero e Ana Lydia Vega ocuparam nos anos noventa “un corpus literario canónico que genera numerosos estudios críticos y que cuenta con cabal reconocimiento". (MARTÍNSEVILLANO, 2012, p. 6).

Diante desse panorama, escritoras negras também conquistaram espaço e visibilidade. Desde então, Mayra Santos-Febres, Yolanda Arroyo Pizarro e Yvonne Denis Rosario, observando tópicos como identidade, nacionalidade, ancestralidade, gênero, racismo, raça e memória, entre outros, contribuíram para confirmar que uma parte da literatura porto-riquenha contemporânea está marcada "por la experiencia de las mujeres" em uma sociedade patriarcal e racista, a qual silenciou vozes e textos de autoria negra feminina. (MARTÍN-SEVILLANO, 2012, p. 6). 
Como se pode observar, longe dos padrões culturais estabelecidos no e pelo cânone literário caribenho, a produção literária de autoria negra abriu espaço para uma extraordinária discussão sobre o processo de democratização da produção literária, bem como para desvelar silenciamentos históricos no contexto da colonização e escravização. Nesse esforço de radical, busca homenagear "a la resistencia, a la rebeldia, a la entrega amorosa" de suas antepassadas para recuperar os laços com a ancestralidade negro-africana. (ARROYO PIZARRO, 2013, p. 108).

\title{
4. DESCOLONIZAÇÃo DO SABER, DO PODER, DO SER EM NARRATIVAS AFRO-DIASPÓRICAS
}

\author{
A los historiadores, \\ por habernos dejado fuera. \\ Aquí estamos de nuevo... \\ cuerpo presente, color vigente, \\ declinándonos a ser invisibles... \\ rehusándonos a ser borradas \\ (ARROYO PIZARRO, 2012, p. 4, grifos meus).
}

Publicado em 2009, o romance Fe en Disfraz de Mayra Santos-Febres é uma obra que revisita a história escravista nas Américas e Caribe. Desde um ponto de vista feminino e negro, a autora porto-riquenha apresenta outra face do universo das mulheres africanas e negras na sociedade colonial, revelando as suas expectativas e vivências, bem como as estratégias de conquista de alforria e os significados de liberdade. Ao traçar outros caminhos epistêmicos, desmantela uma perspectiva eurocêntrica que preserva a centralidade do olhar colonizador (o poder de enunciação de registro dos fatos históricos).

Tendo em vista esse cenário, constrói uma narrativa desvestida de uma cronologia linear, num movimento em que tudo vai e volta, avança e retrocede, os tempos se confundem e se estabelecem em um jogo entre presente, passado e futuro. Dito de outro modo, o romance se sustenta ao que ensaísta negra brasileira Leda Martins (2000, p.79) define como "tempo espiralar". Ao tomar como arcabouço teórico a noção de tempo espiralar, esse assume um protagonismo fundamental para compreender a trama literária, uma vez que, 


\section{Revista \\ Debates Insubmissos}

concomitantemente, os tempos se associam através do resgate das histórias e os legados de luta e resistência negra feminina.

[...] guardaban imágenes de haciendas, vestidos, personajes de la época. Me ponía a leer recuentos de esclavas, sus desventuras a manos de amos disolutos. Respondía mi obelisco henchido ante el relato de sus carnes, recibiendo azotes, abultándose bajo los cueros del castigo [...] la Historia está llena de mujeres anónimas que lograron sobrevivir al deseo del amo desplegándose ante su mirada. [...]. (SANTOS-FEBRES, 2009, p. 45-46).

Para além dos limites do conceito, em diversos momentos, o tempo espiralar ostenta uma "percepção cósmica e filosófica que entrelaça e envolve, no mesmo circuito de significância", um resgate da ancestralidade e da(s) identidade (s) negra(s). (MARTINS, 2000, p.79). Neste palco, com conexões entre raça e gênero, a escrita afro-diaspórica desfaz as estratégias de representação do passado colonial, a partir de diferentes relatos de mulheres escravizadas no Brasil, Costa Rica, Porto Rico, Venezuela etc. Dessa forma, realça uma polissemia de vozes e acrescenta outros pontos de vista sobre a história escravista que impacta no processo de construção da memória coletiva.

Para demonstração de como isso ocorre na obra, as memórias traumáticas de mulheres africanas e negras se entrecruzam aos vários acontecimentos ocorridos entre os séculos XVII, XVIII e XIX - em colônias espanholas e portuguesas, o que revela as dinâmicas e a criação de oportunidades para a resistência. Mesmo diante tanto obstáculos, ao deixarem legados e heranças, essas mulheres falaram de suas vidas, das experiências da escravidão, das suas expectativas por liberdade e emancipação; das suas afetividades e relações familiares, entre outras.

Entonces, y como por arte de magia, en un seminario de la Universidad de Chicago aparecen documentos que el mundo historiográfico suponía inexistentes. Fe recordó los nombres de varias fundaciones que apoyarían su proyecto. Gracias a aquellos documentos, podría presentar una propuesta de investigación que tendiera puentes entre instancias interessadas en estudios de raza e identidad, en estudios de género, y en la defensa de los derechos civiles. Pidió una beca investigativa; se la otorgaron. (SANTOS-FEBRES, 2009, p. 23).

Para além de tão-somente de relatos de mulheres submissas ou expostas à opressão, como mucamas, violentadas sexualmente ou oprimidas pelas relações de gênero, $\mathrm{Fe}$ en Disfraz destaca mulheres que se tornaram fazendeiras ou proprietárias de outros bens que lhes 


\section{Revista \\ Debates Insubmissos}

garantisse autonomia financeira e protagonismo. Por conseguinte, visibiliza registros de abusos físicos e sexuais que levaram as escravizadas a pedir ajuda ao Santo Oficio. Diante de todo esse contexto; além das declarações de atormentações e castigos, com exposições minuciosas de violação de seus corpos, denunciaram as mais diferentes tentativas de desumanização.

[...] declaraciones de tormentos y castigos. Mariana Di Moraes, Diamantina, la mulata Pascuala, los testimonios se sucedian uno tras outro. Relataban estupros y forzamientos con lujo de detalles. Su contenido sexual era particularmente violento. (SANTOS-FEBRES, 2009, p. 21).

Logró dar con otros manuscritos de esclavas, libros de cuentas, actas de bautizo de los hijos que las negras les parieron a sus amos; todos blancos, todos ricos y poderosos. (SANTOS-FEBRES, 2009, p. 23).

Consequentemente, a obra afro-diaspórica se organiza a partir da trajetória de dois personagens: o porto-riquenho Martín Tirado (narrador da maior parte do enredo), um historiador que chega a Chicago para trabalhar sob as ordens de Maria Fernanda Verdejo, ou simplesmente Fe Verdejo, historiadora, pesquisadora e intelectual afro-venezuelana. Por esse enquadramento, os protagonistas vivenciam uma relação amorosa marcada por diversos registros históricos, o que colabora para costura e desenvolvimento do tecido narrativo. Nesse caso, uma síntese pode ajudar na melhor compreensão desta afirmação:

[...] Llegué a Chicago a trabajar con Fe Verdejo cinco años después de que ella armara su famosa exposición de esclavas manumisas de los siglos XVII y XVIII en Latinoamérica”. "[...] las indicaciones de Fe son claras y hay que seguirlas al pie de la letra. Son sus condiciones para nuestro encuentro. Esta vez, me han llegado escuetas, precisas. Debo esperar a que caiga la noche. (SANTOS-FEBRES, 2009, p. 15-16).

Mais do que isso, a autora mobiliza uma estratégia discursiva de fazer da escrita literária uma possibilidade de dar voz aos seus antepassados africanos - retratando a questão da escravidão sob o ponto de vista e vivências das próprias mulheres escravizadas. São elas: Diamantina, Maria, Petrona, Ana María, Pascuala e Xica da Silva. Para compreender essa mudança de roteiro e perspectiva, os espaços são redimensionados para enfatizar a luta pela sobrevivência por toda a diáspora, bem como assinalar insurgências negras contra as relações de poder: 


\section{Revista \\ Debates Insubmissos}

[...] En esa ocasión, declaró la esclava: "que la señora no para de injuriarme, de pegarme con un palo sobre el vientre y empujarme para ocasionarme caídas". Mostró cicatrices de golpes y carnes moradas al veedor, una vez presentada la denuncia. Diamantina pedía la venia para buscar otra casa donde servir y otro amo que la comprara con sus hijos. (SANTOS-FEBRES, 2009, p. 28, grifos da autora).

Seguindo em nossa reflexão, Fe Verdejo é uma museóloga renomada que trabalha em uma universidade, sendo a única mulher e a única negra em seu departamento liderando homens brancos. Desta feita, destaca que se trata de uma mulher negra, inteligente, acadêmica, jovem e com posição econômica herdada de sua avó. Ao problematizar as representações dominantes pelo cânone ocidental e colocar em relevo a trajetória da protagonista, a voz narrativa reconfigura os papeis sociais femininos.

[...] Son hombres de extensa preparación libresca, tan blancos como los pergaminos con los que nos rodeamos para sobrevivir nuestra inadecuada pertenencia al mundo de los vivos. "[...] No son muchas las estrellas académicas con su preparación y que, como Fe, sean, a su vez, mujeres negras. (SANTOS-FEBRES, 2009, pp. 1617).

Ao longo dos capítulos, os tópicos demonstram a obsessão de Fe Verdejo em tornar públicos documentos históricos que narram às denúncias feitas de "las esclavas manumisas". Nesses termos, a protagonista encontra vários arquivos e recupera alguns artefatos de mulheres africanas e negras escravizadas. Soma-se a isso, ao organizar uma exposição, a personagem colabora para inscrever uma linhagem negra feminina. Dentro dessa linha, podese pensar que é uma personagem reflexiva de seu passado, presente e projetar o futuro. Nesse caso, a ancestralidade é um traço comum para estabelecer a ligação com as histórias de suas antepassadas: Diamantina, Maria, Petrona, Ana María e Pascuala e Xica da Silva.

Durante as buscas por esses vestígios, Fe Verdejo se desloca para o Brasil e, ao visitar um monastério, descobre um luxuoso traje que pertenceu a Xica da Silva (1731-1796), mulher negra que se tornou uma das personagens emblemáticas da história colonial brasileira ${ }^{13}$.

\footnotetext{
${ }^{13}$ As referências a Xica da Silva possuem uma simbologia ancestral importante para o desenvolvimento da trama, assim como para as percepções de Fe Verdejo acerca das histórias e os legados de luta e resistência de suas antepassadas. O vestido de Xica da Silva possui uma forte simbologia ancestral, uma vez que, ao vestir o traje, a protagonista revive as feridas abertas pela dominação colonial nos corpos das mulheres negras. Ela passa a pertencer/ se reconhecer nessa linhagem feminina negra que sofreu as agruras do escravismo colonial e a reviver as feridas provocadas por essas recordações. Fe Verdejo reinterpreta essas memórias traumáticas e as subverte.
} 


\title{
neriste \\ Debates Insubmissos
}

Nesse deslocamento pela diáspora, podemos localizar a presença e um legado histórico dos povos africanos: desde o sequestro até o cativeiro no Caribe e nas Américas.

La doctora Verdejo decidió concentrarse en la región brasileña de Minas Gerais, en Tejuco, propiamente, y en su región de explotación de diamantes. De allí procedían los documentos más dramáticos y numerosos. Después, cubriría otros territorios. Preparó su viaje y partió. (SANTOS-FEBRES, 2009, p. 23, grifos meus).

De certa maneira, diante dos achados de Fe Verdejo, ao contrário do que mostram muitos romances canônicos, Santos-Febres situa a resistência negra feminina em um amplo espectro de possibilidades. Visto desse ângulo, ao compreender que a colonialidade do poder, do saber, do ser se sustenta através de uma memória socialmente arquitetada e uniformizada pelo imaginário colonial, a autora consegue afetar o estatuto da própria história cultural e literária, porque instala uma reflexão historiográfica bastante ampla, pois mergulha nas profundezas do atlântico negro:

\begin{abstract}
Algunos de aquellos papeles narraban cómo esclavas manumisas de diversas regiones del Imperio lusitano y del español lograron convertirse en dueñas de hacienda. Otros tan solo recogían testimonios de "abusos", en los cuales las esclavas pedían amparo real. Encontró, además, documentos de condena por el Santo Oficio, declaraciones de tormentos y castigos. Mariana Di Moraes, Diamantina, la mulata Pascuala, los testimonios se sucedían uno tras otro. Relataban estupros y forzamientos con lujo de detalles. Su contenido sexual era particularmente violento. (SANTOS-FEBRES, 2009, p. 22).
\end{abstract}

Ajustando um pouco mais o foco, de várias maneiras, fica evidenciada a coragem, a luta e a resistência de mulheres africanas e negras. Por meio de outras histórias, recolhidas nos documentos - as narrativas adquirem novos olhares para se insubordinar a uma matriz colonial do poder, do saber e do ser. Em sentido mais amplo, além dos levantes, fugas e cimarronajes, nas formas de conhecer, criar e viver, elas praticavam variadas estratégias de insurgência a dominação colonial, inclusive, desenvolvendo ações coletivas para aprender/ensinar a ler e escrever.

[...] Em inglés, existen miles de declaraciones de esclavos que dan su testimonio en contra de la esclavitud. Mujeres educadas que formaban parte de sociedades abolicionistas les enseñaban a leer y a escribir, recogían sus palabras y, luego, financiaban la publicación de esos testimonios para que el público conociera los terrores de la trata. Oludah Equiano, Harriet Jacobs, Mary Prince, Frederich Douglass, esclavos con nombres y apellidos, contaron el infierno de sus vidas bajo el yugo de la esclavitud. (SANTOS-FEBRES, 2009, p. 23, grifos meus). 


\section{nexstat 0 \\ Debates Insubmissos}

Por essa razão, Santos-Febres assenta "los conocimientos y saberes, la memoria ancestral, con la cosmologia" negro-africana. (WALSH, 2008, p. 140). Desse modo, a escritora porto-riquenha provoca uma reação imediata que incide numa ótica de superação a colonialidade epistemológica em oposição a uma epistemologia eurocêntrica.

Recompongo (e ilustro) fragmentos del pasado. Los ofrezco al presente en tiempo
hiperreal, un tiempo que pretende burlar la muerte de lo orgánico, la quietud del
papel, la lentitud de los hechos [...] Vivo (como un monje) suspendido en el tiempo
[...] Vivo callado, embebido en los mudos designios de la Historia. (SANTOS-
FEBRES, 2009, p. 17, grifos meus).

Por sua vez, ao pinçar recortes específicos do romance, vale destacar que as denúncias feitas por "las ancestras" Diamantina, Maria, Petrona, Ana María e Pascuala etc., aparecem nos capítulos III, V, VI, VIII y XII. Nesse âmbito, os relatos reconhecem que as mulheres africanas e negras como sujeitos portadores de direitos, humanidade e protagonismo; reescrevem as memórias instaladas nos corpos das mulheres africanas e negras; reconstroem as imagens de corpos como testemunhos de uma memória negro-africana.

No Capítulo III, entramos em contato com os relatos de la ancestra Diamantina, uma mulher africana feita escrava em Minas Gerais-Brasil. No corpo, três cicatrizes em sua bochecha sugerem que ela pertencia a etnia fula ou fulani, um povo proveniente da África Ocidental. Em nome de seus cinco filhos: Justo, Isidro, Joaquín, Fernando e Ricardo, todos escravizados por “don Tomás de Angueira y de doña Antonia de la Granda y Balbín”, em 1785, em uma "Declaratoria ante el gobernador Alonso de Pires, Aldea de Tejuco, Archivo Histórico de Minas Gerais", ela denuncia a violência colonial praticada por seus algozes. Nos documentos achados por Fe Verdejo, “constaban estos excesos de injurias públicas en la plaza, a la salida de las misas; azotes, empujones". (SANTOS-FEBRES, 2009: 27). Diferentemente das narrativas mais tradicionais da hipersexualização e a desvinculação das mulheres negras à maternidade que as desumanizam, conhecemos a trajetória de uma mulher escravizada que confronta as opressões, violências e hierarquias:

[...] Diamantina declaró haber venido anteriormente a pedir protección real ante el gobernador Alonso Pires, por los excesos cometidos por su ama. Era de edad desconocida, con três incisiones en la mejilla derecha, posiblemente fulá, proveniente de tierras costaneras. [...] "que la señora no para de injuriarme, de 


\section{Revista \\ Debates Insubmissos}

pegarme con un palo sobre el vientre y empujarme para ocasionarme caídas". Mostró cicatrices de golpes y carnes moradas al veedor, una vez presentada la denuncia. Diamantina pedía la venia para buscar otra casa donde servir y otro amo que la comprara con sus hijo (SANTOS-FEBRES, 2009, p. 27).

Nessas circunstâncias, os documentos indicam que as mulheres escravizadas mantiveram vivas as necessidades de mobilização e de resistência contínua. Essas estratégias eram produzidas no seio da sociedade escravocrata. A respeito disso, destacamos um trecho em que Diamantina reivindica o direito à herança para o seu filho mais velho.

Diamantina presenta el testamento ante el gobernador Pires. Pide que se cumpla con las escrituras y que Justo, su hijo mayor, sea oficialmente inscrito como dueño del Trapiche La Paz, según lo dispuesto por su antiguo dueño. (SANTOS-FEBRES, 2009, p. 30).

Em face disso, essas narrativas afro-diaspóricas reabrem feridas "que jorram sangue" por toda a América Latina e Caribe: “[...] Las heridas abiertas despiertan el dolor del pasado, pero como un gesto necesario para imponerse a la renovación de la memoria racial". (RIVERA-CASELLAS, 2011, p. 113). Nesse campo de disputa, potencializando questionamentos e ações anti-hegemônicas, a autora revitaliza a tradição crítica de pensamento latino-americano e caribenho. Ao alinhavarmos os argumentos, Santos-Febres reconstitui um imaginário, transcendendo a relação de dominação e subordinação, retirando do cânone literário e historiográfico o privilégio epistêmico de narrar e contar as histórias de suas antepassadas.

\section{DE LA HERIDA QUE ES RECORDAR}

Fe en disfraz es muchas cosas, pero, también, es uma novela acerca de la memoria, de la herida que es recordar. Está montada sobre documentos falsos, falsificados, reescritos com retazos de declaraciones de esclavos que recogí de múltiples fuentes primarias y secundarias; que recombiné, traduje o que, francamente, inventé. (SANTOS-FEBRES, 2009, p. 117, grifos meus).

De acordo com Marie Ramos Rosado (2012, p. 185), escritoras e intelectuais negras como Mayra Santos-Febres e Yolanda Arroyo Pizarro tratam "la temática raza-génerodiversidad en su literatura, de alguna manera, tienen la negrura a flor de piel". Ao trazer a 


\section{Revista
Debates Insubmissos}

negrura a flor da pele, as personagens femininas são mulheres marginalizadas e invisibilizadas "por la historia oficial en la sociedad puertorriqueña". Em seus escritos, as pensadoras deixam de encarnar "papeles sumisos y domesticados, nunca protagónicos y liberadores" que circulam no imaginário caribenho, oferendo em seus escritos novas epistemologias.

Em uma perspectiva transnacional, Fe en Disfraz se conecta com as seguintes autoras e obras afro-diaspóricas: Úrsula (1869) de Maria Firmina de Jesus (Brasil); Jonatás y Manuela (1994) de Luz Argentina Chiriboga (Uruguai); Las esclavas del Rincón (2001) de Susana Cabrera (México); Ponciá Vicêncio (2003) e Becos da Memória (2006) de Conceição Evaristo (Brasil); Rosalía, la infame (2003) Évelyne Troutillot (Haiti); Um defeito de cor de Ana Maria Gonçalves (2006/Brasil); Malambo (2001) Lucía Charún-Illescas (Peru); Echú y el viento (2006), Tatanene cimarrón (2006) e Cartas para a minha mãe (2010) e de Teresa Cárdenas (Cuba); Bará: na trilha do vento (2015) de Miriam Alves (Brasil); Afuera crece un mundo (2016) de Adelaida Fernández Ochoa (Colômbia); O crime do cais do Valongo (2018) de Eliana Alves Cruz (Brasil), entre outras. Neste sentido, a partir dessa lista, buscamos estabelecer conexões solidárias e transformadoras de produção de conhecimento, bem como demonstrar o reconhecimento de diferentes saberes diaspóricos que desafiam forças hegemônicas.

Diante deste contexto, Yolanda Arroyo Pizarro (2013, p. 35) afirma que em $\mathrm{Fe}$ en Disfraz, Mayra Santos-Febres reescreve as histórias e os legados de "mujeres insurrectas, cimarronas subversivas, transcorpóreas que piedieron voz, cuerpo, armas y venganza". Mediante a construção de uma inteligibilidade e novas tessituras político-epistêmicas, desafiando a razão colonial e ocidental, Santos-Febres reescreve outra história negra feminina. Por esse raciocínio, cabe ressaltar também que as escritoras negras caribenhas se reencontram, reconectam-se as suas antepassadas para reencenar novos "actos de rebeldia". (ARROYO PIZARRO, 2013, p. 41). 


\section{REFERÊNCIAS}

ARROYO PIZARRO, Yolanda A. Hablar de las ancestras: hacia una nueva literatura insurgente de la afrodescendencia". In: Tongas, palenques y quilombos: ensayos y columnas de afroresistencia. Latoya Hobbs, Porto Rico, 2013, 23-43.

ARROYO PIZARRO, Yolanda A. las Negras. Carolina: Boreales, 2012.

BERNARDINO-COSTA, Joaze; GROSFOGUEL, Ramón. Decolonialidade e perspectiva negra. Sociedade e Estado, Brasília, v. 31, n. 1, jan./abr. 2016.

CARNEIRO, A. S. A. Construção do Outro como Não-ser como fundamento do Ser. São Paulo: FUESP, 2005.

GROSFOGUEL, R. Para descolonizar os estudos de economia política e os estudos póscoloniais: transmodernidade, pensamento de fronteira e colonialidade global. Revista Crítica de Ciências Sociais, n. 80, 2008, p. 115-147.

GROSFOGUEL, Ramón. Dilemas dos estudos étnicos norte-americanos: multiculturalismo identitário, colonização disciplinar e epistemologias descoloniais. Ciência e cultura, v. 59, n. 2, 2007, p. 32-35.

GROSSFOGUEL; Ramón. A estrutura do conhecimento nas universidades ocidentalizadas: racismo/sexismo epistêmico e os quatro genocídios/epistemicídios do longo século XVI. Revista Sociedade e Estado - Volume 31 Número 1 Janeiro/Abril, 2016.

HARDING, Rachel Elizabeth. (2016). Você tem direito à árvore da vida: spirituals afroamericanas e religiões da diáspora. Tradução de Christine J. Eida e Mariana Gadelha". In: REIS, Isabel Cristina F. dos; ROCHA, Solange P. Diáspora africana nas Américas. Cruz das Almas: EDUFRB; Belo Horizonte: Fino Traço, (Coleção Uniafro, 5).

HOOKS, Bell. Erguer a voz: pensar como feminista, pensar como negra. Tradução de Cátia Bocaiuva Maringolo. São Paulo: Elefante, 2019.

HOOKS, Bell. Intelectuais negras. Revista de Estudos feministas, Florianópolis, v. 3, n.2, p. 464-478, ago./dez, 1995.

MALDONADO-TORRES, Nelson. "Transdisciplinaridade e Decolonialidade". Revista Sociedade e Estado - Volume 31 Número 1 Janeiro/Abril, 2016.

MALDONADO-TORRES, Nelson. A topologia do ser e a geopolítica do conhecimento: modernidade, império e colonialidade. In: SANTOS, Boaventura de S. Santos; MENESES, M. Paula (Orgs.). Epistemologias do Sul. Coimbra: CES, 2009.

MALDONADO-TORRES, Nelson. Sobre la colonialidad del ser: contribuciones al desarrollo de un concepto. In: CASTRO-GÓMEZ, Santiago; GROSFOGUEL, Ramón (orgs.). El giro decolonial: reflexiones para una diversidad epistémica más allá del capitalismo global. Bogotá: Siglo del Hombre, 2007. 
MARTINS, Leda Maria. Afrografias da Memória. Editora Perspectiva, 1995.

MARTÍN-SEVILLANO, Ana Belén. Escritura y mujer en Puerto Rico hoy. In: Escritoras puertorriqueñas en el siglo XXI: creación y crítica. TINKUY $\mathrm{n}^{\circ} 18$, Section d'études hispaniques Université de Montréal, 2012.

MIGNOLO, W. D. Desobediência Epistêmica: a opção descolonial e o significado de identidade em política. Trad. Ângela Lopes Norte. In: Cadernos de Letras UFF - Dossiê: Literatura, Língua e Identidade, $n^{\circ} 34,2008$, p. 287-324.

MIGNOLO, Walter D. La idea de américa latina: la herida colonial y la opción decolonial. Barcelona: Gedisa, 2005.

MIGNOLO, Walter D. Novas reflexões sobre "Ideia da América Latina": a direita, a esquerda e a opção descolonial. Caderno CRH, v.21, n.53, 2008, p. 239-252.

OQUENDO-VILLAR, Carmen Mayra Santos-Febres e Os Escritores Boricua do Século XXI (versão em espanhol). Disponível em <https://archive.revista.drclas.harvard.edu/book/mayrasantos-febres-y-las-escritoras-boricuas-del-siglo-xxi-spanish-version>. (acesso em 26/12/2020).

QUIJANO, Aníbal. Colonialidade do poder e classificação social. In: SANTOS, Boaventura de Sousa; Meneses, Maria Paula (Orgs.). Epistemologia do Sul. São Paulo: Cortez, 2009, p. 84-130.

QUIJANO, Aníbal. Colonialidade do poder, eurocentrismo e América Latina. In: LANDER, Edgardo. A colonialidade do saber: eurocentrismo e ciências sociais. Buenos Aires: Consejo Latinoamericano de Ciencias Sociales - CLACSO, 2005, p. 107-130.

RAMOS ROSADO, Marie. Mujeres negras y mulatas en tres narradoras puertorriqueñas: Rosario Ferré, Mayra Santos Febres e Yvonne Denis Rosario, Destellos de la negritud: Investigaciones caribeñas. San Juan : Isla Negra, 2011, 117-134

RIVERA-CASELLAS, Zaira. La poética de la esclavitud (silenciada) en la literatura puertorriqueña: Carmen Colón Pellot, Beatriz Berrocal, Yolanda Arroyo Pizarro y Mayra Santos Febres. Cincinnati Romance Review 30.Special Issue on Afro-Hispanic Subjectivities, 2011, 99-116.

ROMÁN SAMOT, Wilkins. Escribir es mi vida misma" realizada por Wilkins Román Samot. Disponível em <https://letralia.com/entrevistas/2020/01/26/mayra-santos-febres> (último acesso em 01/12/2020).

RUBIO MBOMÍO, Lucía Asué. Ser negra es la razon primordial por la cual soy escritora. Disponível em <https://afrofeminas.com/2015/07/01/ser-negra-es-la-razon-primordial-por-lacual-soy-escritora-entrevista-a-mayra-santos-febres>. (último acesso em 01/12/2020). 
SALES, Cristian Souza de. Assentamentos de resistência: intelectuais negras do Brasil e Caribe em insurgências epistêmicas. Tese apresentada ao Programa de Pós-graduação em Literatura e Cultura. Salvador: UFBA, 2020.

SALES, Cristian Souza de. Mayra Santos-Febres: Gestos Performativos De Uma Intelectual Afrocaribenha". Anais do VII Seminário Internacional e XVI Seminário Nacional Mulher e Literatura / org. André Tessaro Pelinser ... [et al.]. - Caxias do Sul, RS : Educs, 2016, p-805-813.

SALES, Cristian Souza de. Negras Grafias Contemporâneas: das escrevivências aos Gestos Performativos. Muiraquitã, UFAC, v. 6, n. 2, 2018.

SALES, Cristian Souza de. Performatividade Intelectual Afro-Caribenha em Por Boca Propia, de Mayra Santos-Febres. Anais do IV Encontro Internacional de Literaturas, Histórias e Culturas Afro-brasileiras e Africanas. Universidade Estadual do Piauí-UESPI-TeresinaPiauí-Brasil. Disponível em <https://silo.tips/download/performatividade-intelectual-afrocaribenha-em-por-boca-propia--2>. (último acesso em 10/12/2020).

SANTOS, Boaventura de Souza. Para Além do pensamento abissal: das linhas globais a uma ecologia dos saberes. In: SANTOS, Boaventura de Souza; MENEZES, Maria Paula (Org.). Epistemologias do Sul. Coimbra, Portugal: Cortez Editora, 2010, p. 31- 83.

SANTOS, Boaventura de Souza. Pela Mão de Alice. São Paulo: Cortez Editora, 1995.

SANTOS-FEBRES, Mayra. (2010). Raza en la cultura puertorriqueña. In: Sobre Piel y papel: ensayos. $2^{\text {a }}$ edición. Ediciones Callejón, 2010, p. 132-156.

SANTOS-FEBRES, Mayra. Cualquier miércoles soy tuya. Barcelona: Mondadori, 2002.

SANTOS-FEBRES, Mayra. Fe en disfraz. Guaynabo: Alfaguara, 2009.

SANTOS-FEBRES, Mayra. La piel que escribo: conversando con mujeres escritoras afroboricuas. Disponível: <https:// www.claridadpuertorico.com/la-piel-que..-escriboconversando-con-mujeres-escritoras-afroboricuas>. (último acesso em 13/12/2020).

SANTOS-FEBRES, Mayra. Nuestra Señora de la Noche. Madrid: Espasa, 2006.

SANTOS-FEBRES, Mayra. Por boca propia. In: Sobre Piel y papel: ensayos. $2^{\mathrm{a}}$ edición. Ediciones Callejón, 2010, p-67-71.

SANTOS-FEBRES, Mayra. Sirena Selena vestida de pena. Barcelona: Mondadori, 2000.

SANTOS-FEBRES, Mayra. Sobre Piel y papel: ensayos. $2^{a}$ edición. Ediciones Callejón, 2010.

VALLADARES-RUIZ, Patrícia. El cuerpo sufriente como lugar de memoria en Fe en disfraz, de Mayra Santos-Febres. Revista Javeriana. Vol. 20 Núm. 40, 2016. 
WALSH, Catherine (Ed.). Pedagogías decoloniales: prácticas insurgentes de resistir, (re)existir y (re)vivir. In: Educação Intercultural na América Latina: entre concepções, tensões e propostas. Vera Maria Candau (Org.). Rio de Janeiro: 7letras, p. 12-39, 2009.

WALSH, Catherine. Interculturalidad, plurinacionalidad y decolonialidad: las insurgencias político-epistémicas de refundar el Estado. Tabula Rasa, Bogotá, n. 9, 2008, p. 131-152, jul./dec.

WALSH, Catherine. Introducion - (Re)pensamiento crítico y (de) colonialidad. In: WALSH, C. Pensamiento crítico y matriz (de)colonial. Reflexiones latino-americanas. Quito: Ediciones Abya-yala, 2005, p. 13-35.

WEST, Cornel. O dilema do intelectual negro. In: The Cornel West: reader. Basic Civitas Books, 1999, [1985].

Recebido: 11/03/2021

Aprovado: 16/05/2021 